out of touch with the aspirations of their national minorities and with the mood of the victorious Allies. There obviously was a failure to recognize the fact that Hungary, because the Hungarian revolution of October 1918 had come too late to affect the course of the war, could expect to be treated as a defeated power regardless of changes in political leadership. As the author points out, France had the dominant voice in Allied policy toward Hungary during this period and French attitudes were determined largely by the requirements of the faltering intervention in Russia and by the demands of the successor states. Having fought for the Entente against the Central Powers, Czechs, Rumanians, and Serbs were now being called upon to supply troops for the anti-Bolshevik campaign in Russia. Thus, a shared hostility to bolshevism merely added a potent ideological dimension to a relationship forged in wartime between France and some of the subject nationalities of the Habsburg lands. Yet to assert that "France needed little prodding to make the area a French Mittcleuropa" is to assume a capacity for dominance that was far beyond French economic and military resources in 1918-19.

Some of the material presented suffers from a lack of critical analysis, particularly with regard to the corrosive effects of nationalism in undermining Karolyi's liberal democratic experiment. Much of the evidence suggests that the adoption of "Wilsonian" or "Leninist" ideals in government was primarily a matter of expediency and that the wellspring of both was a nationalism outraged by the prospect of crippling territorial losses.

IOANNIS Sinanoglou

New York City

\title{
DAS WIRTSCHAFTSLENKUNGSSYSTEM DES UNGARISCHEN SOZIA- LISMUS: ENTWICKLUNGEN SEIT 1968. By Endre Antal. Untersuchungen zur Gegenwartskunde Südosteuropas, 10. Munich: R. Oldenbourg Verlag, 1976. 179 pp. Tables. DM 25, paper.
}

This book describes and to some extent attempts to analyze the establishment (1968), evolution, and impact of the celebrated Hungarian New Economic Mechanism (NEM). The first two chapters discuss the ideological and institutional foundations of the Hungarian economic system and the principal "reforms" of the NEM, which were designed to increase competition and economic efficiency. These changes included the elimination of most detailed central planning of production (devolving this responsibility to individual enterprises responding to market forces), introduction of flexible prices on some products, linkage of foreign and domestic prices for a subset of traded goods, and other departures from "Soviet-type" central planning. Antal characterizes the NEM as a socialist indicative-plan economy (Rahmenplanzvirtschaft), a mixture of plan and market.

The following six chapters deal with specific aspects of the Hungarian econony: investment, credit, and price policy; enterprise policy; industry; agriculture; transportation and services; and foreign trade. The latter is not discussed extensively, however, which is rather curious given the atthor's stress on Hungary's great dependence on foreign trade and the pivotal role it was designed to play in the overall NEM. A final chapter, devoted to the "effects" of the NEM, is disappointing because Antal does not really attempt an overall analysis or evaluation of the NEM in terms of its stated purposes and internal and external constraints.

Perhaps most interesting is the postscript, written after the announcement in early 1976 of further changes in economic regulations which, the author suggests, tended to strengthen recentralization tendencies already observable in 1972-73. Antal presents an impressive catalog of recent recentralizing measures, and asks (but does 
not answer) whether these changes represent a fundamental movement away from the reform path of the late 1960s, or possibly even the end of the NEM. Another question, not posed by the author, is to what extent recentralization has been primarily a response to severe internal economic and political pressures, external economic disturbances (inflation, deteriorating terms of trade, Western recession), or political (and more recently, economic) pressures from the East. An answer to this question might help in evaluating the prospects for the "reform" to get back on course if and when the external economic environment improves.

Thomas A. Wolf

Ohio State University

VIAGGIO IN DALMAZIA, I, II (1774). By Alberto Fortis. Munich and Sarajevo: Verlag Otto Sagner and Izdavačko preduzeće "Veselin Masleša," 1974. 486 pp. DM 72.

It is most appropriate that Viaggio in Dalmazia by Alberto Fortis was republished in the bicentennial year of its original appearance. The book describes the travels through Dalmatia of the Venetian abbot and scholar in a clear and systematic way. Fortis's trips took him from Zadar in the north to Neretva in the south, through parts of the rugged Dalmatian hinterland, and to some of the main offshore islands. His descriptions and remarks are a sheer delight to read and they offer an immense wealth of information on numerous topics. An open-minded and sharp observer, Fortis fills his text with detailed geological descriptions; essays on the sea, shells, fish, and fishing; discussions of rivers and lakes, their positive and negative impacts on the environment; and so forth. More important, he explains vividly and intelligently the habits and ways of life of the local populations, dealing with such things as their dress, food, and housing. Of particular interest are the author's careful descriptions of archaeological sites, inscriptions, and monuments-many of them now lost-and his frequent references to ancient manuscripts that he inspected in various places.

Most fascinating, perhaps, is Fortis's attempt to go beyond mere description and listing of what he saw. In a clear and perceptive manner, he criticizes mercilessly all the negative things he observed, including administrative negligence and inefficiency, ecclesiastical narrow-mindedness and selfishness, economic underdevelopment and missed opportunities, and the backwardness and primitiveness of the people he encountered. But he does not stop there. Fortis goes beyond criticism to make suggestions for improvements in many areas. Some of his criticisms and suggestionsespecially those concerning economics-have an uncannily modern sound. In this regard, and very applicable to our own times, are his complaints about the abuses and destruction of archaeological treasures and his marvelously progressive ideas for their conservation.

There is no doubt that specialists will find many naive interpretations and erroneous statements in this work. Nevertheless, no other traveler of his day left such a rich mine of knowledge and such an abundant and accurate source of information about a relatively little known province. Fortis has done a truly remarkable, indeed extraordinary, job in this respect. He deserves our gratitude. Recognition is also due to Jovan Vuković of Sarajevo, who writes a short but useful introduction, and to Peter Rehder of Munich, who contributes a valuable-albeit too short-bibliography on Fortis.

Altogether, Fortis's book reflects a vigorous intellect, an excellent education, and an inquisitive mind. It is a joy to read and an unending source of discoveries. 